\title{
Summary of 2010 DOE EM International Program Studies of Waste Glass Melt Rate Enhancement
}

K. M. Fox

J. C. Marra

A. S. Aloy

December 2010

Savannah River National Laboratory Savannah River Nuclear Solutions, LLC Aiken, SC 29808

Prepared for the U.S. Department of Energy under contract number DE-AC09-08SR22470.

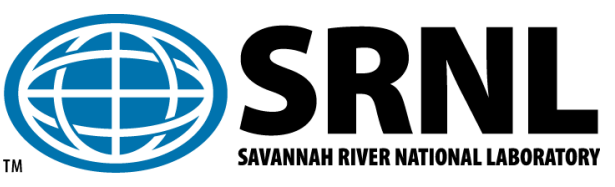


SRNL-STI-2010-00811

Revision 0

\section{DISCLAIMER}

This work was prepared under an agreement with and funded by the U.S. Government. Neither the U.S. Government or its employees, nor any of its contractors, subcontractors or their employees, makes any express or implied:

1. warranty or assumes any legal liability for the accuracy, completeness, or for the use or results of such use of any information, product, or process disclosed; or

2. representation that such use or results of such use would not infringe privately owned rights; or

3. endorsement or recommendation of any specifically identified commercial product, process, or service.

Any views and opinions of authors expressed in this work do not necessarily state or reflect those of the United States Government, or its contractors, or subcontractors.

\section{Printed in the United States of America \\ Prepared for \\ U.S. Department of Energy}




\section{REVIEWS AND APPROVALS}

AUTHORS:

K. M. Fox, Process Technology Programs

Date

J. C. Marra, DOE-EM Office of Technology Innovation and Development

Date

TECHNICAL REVIEW:

D. K. Peeler, Process Technology Programs

Date

APPROVAL:

C. C. Herman, Manager

Date

Process Technology Programs

S. L. Marra, Manager

Date

Environmental \& Chemical Process Technology Research Programs 


\section{ACKNOWLEDGEMENTS}

The authors would like to thank the skilled research team at the V. G. Khlopin Radium Institute for their work in fabricating the melter feeds and conducting the melt rate experiments. The authors would also like to thank Irene Reamer, Phyllis Workman, David Best, Patricia Simmons, Whitney Riley, and David Missimer at SRNL for their assistance with characterizing the study glasses, and Dr. Tanya Albert for skilled translations. The authors acknowledge the International Program at the U.S. Department of Energy Office of Environmental Management for financial support of this work. 
SRNL-STI-2010-00811

Revision 0

\section{EXECUTIVE SUMMARY}

A collaborative study has been established under the U.S. Department of Energy (DOE) Office of Environmental Management International Program between the Savannah River National Laboratory (SRNL) and the V. G. Khlopin Radium Institute (KRI) in St. Petersburg, Russia, to investigate potential improvements in melt rate via chemical additions to the glass frit. Researchers at KRI suggested a methodology for selecting frit additives based on empirical coefficients for optimization of glass melting available in the Russian literature. Using these coefficients, KRI identified $\mathrm{B}_{2} \mathrm{O}_{3}, \mathrm{CuO}$, and $\mathrm{MnO}$ as frit additives that were likely to improve melt rate without having adverse effects on crystallization of the glass or its chemical durability.

The results of the melt rate testing in the SMK melter showed that the slurry feed rate (used as a gauge of melt rate) could be significantly increased when $\mathrm{MnO}$ or $\mathrm{CuO}$ were added to Frit 550 with the SMR-2 sludge. The feed rates increased by about $27 \%$ when $\mathrm{MnO}$ was added to the frit and by about $26 \%$ when $\mathrm{CuO}$ was added to the frit, as compared to earlier results for Frit 550 alone. The impact of adding additional $\mathrm{B}_{2} \mathrm{O}_{3}$ to the frit was minor when added with $\mathrm{CuO}$. The additional $\mathrm{B}_{2} \mathrm{O}_{3}$ showed a more significant, $39 \%$ improvement in melt rate when added with $\mathrm{MnO}$. The additional $\mathrm{B}_{2} \mathrm{O}_{3}$ also reduced the viscosity of the glasses during pouring. Samples of the glasses from the melt rate testing characterized at SRNL showed that there were no significant impacts on crystallization of the glasses. All of the glasses had very good chemical durability. Chemical composition measurements showed that the frit additives were present in concentrations below the targeted values in some of the glasses. Therefore, it is possible that higher concentrations of these additives may further improve melt rate, although the impacts of higher concentrations of these components on crystallization and durability would need to be determined. Overall, the results show an excellent potential for these additives to significantly improve waste throughput for DOE vitrification facilities. A complete report from KRI is included as an appendix to this document. 


\section{TABLE OF CONTENTS}

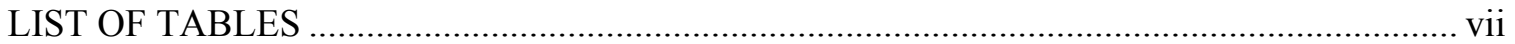

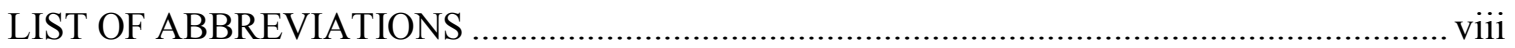

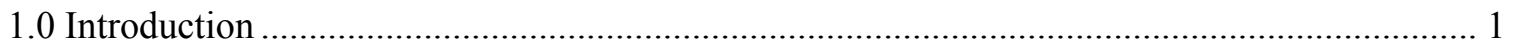

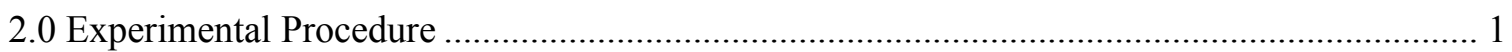

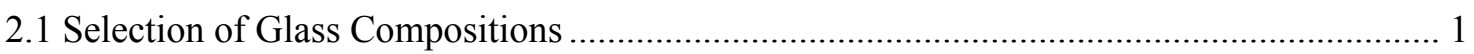

2.2 Fabrication of Feeds and Melt Rate Testing .................................................................. 2

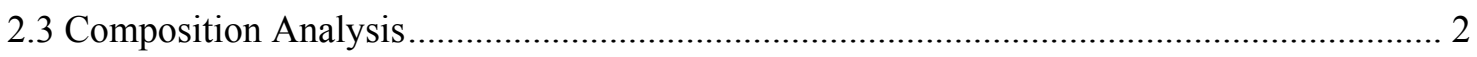

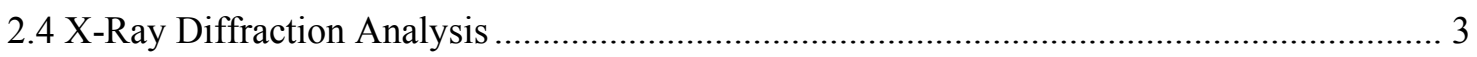

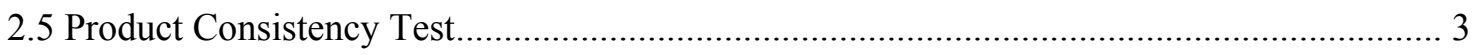

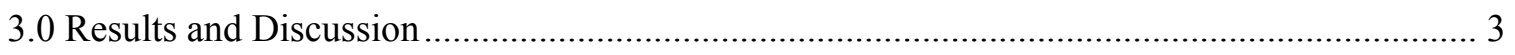

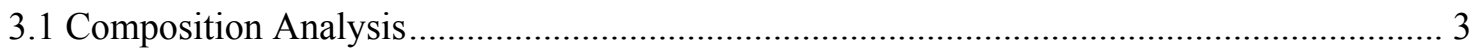

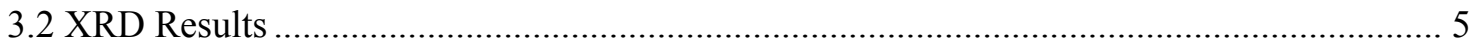

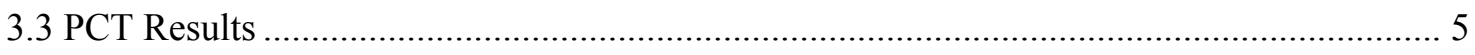

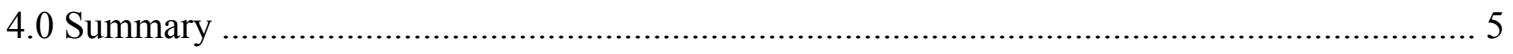

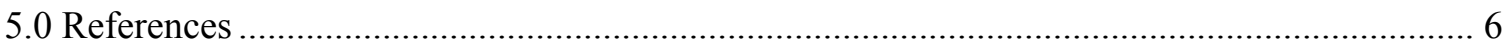




\section{LIST OF TABLES}

Table 2-1. Targeted Compositions of the Frits Selected for Melt Rate Testing............................ 1

Table 2-2. Targeted Compositions for the Study Glasses (wt \%)............................................ 2

Table 3-1. Targeted and Measured Compositions of the Study Glasses (wt \%).......................... 4

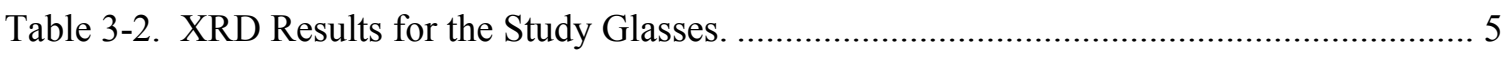

Table 3-3. PCT Results for the Study Glasses and EA. …................................................................ 5 


\section{LIST OF ABBREVIATIONS}

$\begin{array}{ll}\text { AD } & \text { Analytical Development } \\ \text { ARM } & \text { Approved Reference Material } \\ \text { CCC } & \text { Canister Centerline Cooled } \\ \text { DOE } & \text { U.S. Department of Energy } \\ \text { DWPF } & \text { Defense Waste Processing Facility } \\ \text { EA } & \text { Environmental Assessment } \\ \text { HLW } & \text { High Level Waste } \\ \text { ICP-AES } & \text { Inductively Coupled Plasma - Atomic Emission Spectroscopy } \\ \text { KRI } & \text { V.G. Khlopin Radium Institute } \\ \text { LM } & \text { Lithium Metaborate } \\ \text { NL } & \text { Normalized Leachate } \\ \text { PCT } & \text { Product Consistency Test } \\ \text { PF } & \text { Peroxide Fusion } \\ \text { PSAL } & \text { Process Science Analytical Laboratory } \\ \text { SMK } & \text { Steklo Metallicheskie Konstruktsii } \\ \text { SRNL } & \text { Savannah River National Laboratory } \\ \text { SRS } & \text { Savannah River Site } \\ \text { XRD } & \text { X-ray Diffraction }\end{array}$




\subsection{Introduction}

The rate of melting of a high level waste (HLW) glass batch is an important factor in waste throughput, or the speed with which an amount of waste can be immobilized into a durable form per unit time. New methods for increasing melt rate will reduce the time and expense associated with the clean up of U.S. Department of Energy (DOE) sites across the country and other legacy nuclear facilities worldwide. The Defense Waste Processing Facility (DWPF) at the Savannah River Site (SRS) uses a Joule heated melter to vitrify HLW blended with a glass frit. Bubblers have recently been added to the melter to agitate the molten glass pool and improve melt rate. Chemical additives in the glass frit may offer an opportunity to further increase melt rate, and would not require any physical modifications to the facility or any changes in operating procedure.

A collaborative study has been established under the DOE Office of Environmental Management International Program between the Savannah River National Laboratory (SRNL) and the V. G. Khlopin Radium Institute (KRI) in St. Petersburg, Russia, to investigate potential improvements in melt rate via chemical additions to the glass frit. Researchers at KRI suggested a methodology for selecting frit additives based on empirical coefficients for optimization of glass melting available in the Russian literature. ${ }^{a}$ Using these coefficients, KRI identified $\mathrm{B}_{2} \mathrm{O}_{3}, \mathrm{CuO}$, and $\mathrm{MnO}$ as frit additives that were likely to improve melt rate without having adverse effects on crystallization of the glass or its chemical durability.

This report describes the selection of simulated sludge and glass frit compositions for melt rate testing at KRI. Complete details of the feed preparation and melt rate experiments are provided in a report from KRI, which is included as Appendix A. Samples of the glasses from KRI were returned to SRNL for further characterization. Based on these results, recommendations are made for selecting frit additives for improving the melt rate of HLW glass batches.

\subsection{Experimental Procedure}

\subsection{Selection of Glass Compositions}

Earlier melt rate testing at KRI of simulated SRS sludge compositions identified a frit composition that provided good melting characteristics and a good quality glass waste form with a high aluminum concentration sludge. ${ }^{\mathrm{b}}$ This frit is identified as Frit 550, and its composition is given in Table 2-1. Frit 550 was therefore used as the basis for the frit additive study. Additions of $\mathrm{B}_{2} \mathrm{O}_{3}, \mathrm{CuO}$, and $\mathrm{MnO}$, as recommended by KRI, were made to the base Frit 550 composition as shown in Table 2-1.

Table 2-1. Targeted Compositions of the Frits Selected for Melt Rate Testing.

\begin{tabular}{|c|c|c|c|c|c|c|c||}
\hline SRNL ID & KRI ID & $\mathbf{B}_{\mathbf{2}} \mathbf{O}_{\mathbf{3}}$ & $\mathbf{C u O}$ & $\mathbf{L i}_{\mathbf{2}} \mathbf{O}$ & $\mathbf{M n O}$ & $\mathbf{N a}_{\mathbf{2}} \mathbf{O}$ & $\mathbf{S i O}_{\mathbf{2}}$ \\
\hline Frit 550 & Frit 1 & 12 & 0 & 8 & 0 & 7 & 73 \\
\hline- & Frit 4 & 11.22 & 6.54 & 7.48 & 0 & 6.54 & 68.22 \\
\hline- & Frit 5 & 11.22 & 0 & 7.48 & 6.54 & 6.54 & 68.22 \\
\hline- & Frit 11 & 15.17 & 6.25 & 7.14 & 0 & 6.25 & 65.18 \\
\hline- & Frit 12 & 15.17 & 0 & 7.14 & 6.25 & 6.25 & 65.18 \\
\hline
\end{tabular}

\footnotetext{
${ }^{a}$ See for example, A. N. Dewalter, Crystal, Colored and Opal Glasses, State Scientific and Technical Publishing House of the USSR Ministry of Light Industry, Moscow (1957); A. A. Appen, Chemistry of Glass, Khimiya Publishing House, p. 18 (1974); L. I. Demkina, Glass and Ceramics, Volume 10, p. 22 (1960).

${ }^{\mathrm{b}}$ See laboratory notebook WSRC-NB-2006-00187 for further detail of this testing.
} 
The high aluminum concentration sludge composition was developed as a representation of future sludges that will need to be vitrified at SRS, and is designated as SMR-2. ${ }^{1}$ In general, sludges containing higher aluminum concentrations can be challenging to melt quickly. Therefore, the use of SMR-2 was continued for this study. The four frits with additives recommended by KRI (Table 2-1) were combined with the SMR-2 sludge at a waste loading of $38 \mathrm{wt} \%$ to allow for comparisons with the previous melt rate testing that used Frit 550 at this waste loading. The targeted compositions of these glasses are given in Table 2-2.

Table 2-2. Targeted Compositions for the Study Glasses (wt \%).

\begin{tabular}{|c|c|c|c|c|}
\hline Oxide & Frit 4 Glass & Frit 5 Glass & Frit 11 Glass & Frit 12 Glass \\
\hline $\mathrm{Al}_{2} \mathrm{O}_{3}$ & 9.61 & 9.61 & 9.61 & 9.61 \\
\hline $\mathrm{B}_{2} \mathrm{O}_{3}$ & 6.96 & 6.96 & 9.41 & 9.41 \\
\hline $\mathrm{BaO}$ & 0.09 & 0.09 & 0.09 & 0.09 \\
\hline $\mathrm{CaO}$ & 1.09 & 1.09 & 1.09 & 1.09 \\
\hline $\mathrm{CdO}$ & 0.23 & 0.23 & 0.23 & 0.23 \\
\hline $\mathrm{Ce}_{2} \mathrm{O}_{3}$ & 0.11 & 0.11 & 0.11 & 0.11 \\
\hline $\mathrm{Cr}_{2} \mathrm{O}_{3}$ & 4.09 & 0.03 & 3.91 & 0.03 \\
\hline $\mathrm{CuO}$ & 12.81 & 12.81 & 12.81 & 12.81 \\
\hline $\mathrm{Fe}_{2} \mathrm{O}_{3}$ & 0.08 & 0.08 & 0.08 & 0.08 \\
\hline $\mathrm{La}_{2} \mathrm{O}_{3}$ & 0.08 & 0.08 & 0.08 & 0.08 \\
\hline $\mathrm{Li}_{2} \mathrm{O}$ & 4.64 & 4.64 & 4.43 & 4.43 \\
\hline $\mathrm{MgO}_{\mathrm{MnO}}$ & 0.17 & 0.17 & 0.17 & 0.17 \\
\hline $\mathrm{Na}_{2} \mathrm{O}$ & 1.66 & 5.72 & 1.66 & 5.54 \\
\hline $\mathrm{NiO}_{\mathrm{PbO}}^{12.48}$ & 12.48 & 12.30 & 12.30 \\
\hline $\mathrm{SO}_{4}$ & 0.48 & 0.48 & 0.48 & 0.48 \\
\hline $\mathrm{SiO} \mathrm{O}_{2}$ & 0.10 & 0.10 & 0.10 & 0.10 \\
\hline $\mathrm{TiO}_{2}$ & 0.00 & 0.00 & 0.00 & 0.00 \\
\hline $\mathrm{ZnO}$ & 0.69 & 43.69 & 41.81 & 41.81 \\
\hline $\mathrm{ZrO}_{2}$ & 0.21 & 1.37 & 1.37 & 1.37 \\
\hline
\end{tabular}

\subsection{Fabrication of Feeds and Melt Rate Testing}

SRNL provided KRI with a composition and method of fabrication for the SMR-2 simulated sludge composition. ${ }^{2}$ Details of the simulated sludge fabrication are given in the final report from KRI, which is included as Appendix A. KRI also fabricated the four frits based on the Frit 550 composition with additives, as described earlier. Melt rate testing was performed in the Steklo Metallicheskie Konstruktsii (SMK) melter at KRI. A description of the SMK melter system, details of the melt rate testing, and the results are included in the report from KRI in Appendix A.

\subsection{Composition Analysis}

To confirm that the glass samples met the targeted compositions, a pour stream sample was pulled and air quenched during the later portion of each melter run, and then submitted to the SRNL Process Science Analytical Laboratory (PSAL) for chemical analysis. Two dissolution techniques, sodium peroxide fusion (PF) and lithium-metaborate (LM), were used to prepare the glass samples for analysis. Each of the samples was analyzed, twice for each element of interest, by Inductively Coupled Plasma - Atomic Emission Spectroscopy (ICP-AES). 


\subsection{X-Ray Diffraction Analysis}

Representative samples of each of the four study glasses were submitted to SRNL Analytical Development (AD) for X-ray Diffraction (XRD) analysis. Samples of the glasses made with Frit 4 and Frit 12 that had been heat treated following the canister centerline cooling (CCC) schedule $^{3}$ were also included. The samples were run under conditions providing a detection limit of approximately $0.5 \mathrm{vol} \%$. That is, if crystals (or unincorporated batch material) were present at $0.5 \mathrm{vol} \%$ or greater, the diffractometer would not only be capable of detecting the crystals but would also allow a qualitative determination of the type of crystal(s) present. Otherwise, a characteristically high background signal (amorphous hump) devoid of crystalline peaks indicates that the glass is free of crystallization, suggesting either a completely amorphous product or that the degree of crystallization is below the detection limit.

\subsection{Product Consistency Test}

The Product Consistency Test (PCT) Method- $\mathrm{A}^{4}$ was performed in triplicate on each quenched and CCC glass to assess chemical durability. Also included in the experimental test matrix was the Environmental Assessment (EA) benchmark glass, ${ }^{5}$ the Approved Reference Material (ARM) glass, ${ }^{6}$ and blanks from the sample cleaning batch. Samples were ground, washed, and prepared according to the standard procedure. ${ }^{4}$ Fifteen milliliters of Type-I ASTM water were added to $1.5 \mathrm{~g}$ of glass in stainless steel vessels. The vessels were closed, sealed, and placed in an oven at $90 \pm 2{ }^{\circ} \mathrm{C}$ where the samples were maintained at temperature for 7 days. Once cooled, the resulting solutions were sampled (filtered and acidified), then labeled and analyzed by PSAL using ICP-AES. Normalized leachate (NL) values were calculated based on the measured compositions using the average of the common logarithms of the leachate concentrations.

\subsection{Results and Discussion}

\subsection{Composition Analysis}

The results of the chemical composition measurements of the study glasses are shown in Table 3-1. The measured values are the mean of two measurements from the ICP-AES instrument. The targeted concentrations and the percent difference between the targeted and measured values are also given in the table. Most of the constituents of the glasses with targeted concentrations of more than $0.5 \mathrm{wt} \%$ are within $10 \%$ of the targeted values. A review of the data in Table 3-1 shows that the $\mathrm{B}_{2} \mathrm{O}_{3}$ concentrations for the glasses made with Frit 11 and Frit 12 are low. The $\mathrm{CuO}$ concentration in the glass made with Frit 4 is low, but is close to the targeted value for the glass made with Frit 11. It appears that $\mathrm{La}_{2} \mathrm{O}_{3}$ was either not included in the glass or was below the detection limit. The $\mathrm{MnO}$ concentrations are below the targeted values for the glasses made with Frit 5 and Frit 12. The sulfate values are high for all of the glasses. Overall, these results show that several of the components added to the frit for a potential increase in melt rate (i.e., $\mathrm{B}_{2} \mathrm{O}_{3}$ in the glasses made with Frit 11 and Frit 12, $\mathrm{CuO}$ in the glasses made with Frit 4, and $\mathrm{MnO}$ in the glasses made with Frit 5 and Frit 12) may have been added in concentrations below the targeted values or may have experienced some volatilization during melting. Therefore, the impacts of these components on melt rate may not be as significant as they might have been if they were included at their targeted concentrations, although they should still have a measurable effect. It would be useful in future work to determine whether the low $\mathrm{B}_{2} \mathrm{O}_{3}$ and $\mathrm{MnO}$ values are due to volatilization when they are added to the glasses at increased concentrations. 
Table 3-1. Targeted and Measured Compositions of the Study Glasses (wt \%).

\begin{tabular}{|c|c|c|c|c|c|c|c|c|c|c|c|c|}
\hline \multirow{2}{*}{ Oxide } & \multicolumn{3}{|c|}{ Frit 4 Glass } & \multicolumn{3}{|c|}{ Frit 5 Glass } & \multicolumn{3}{|c|}{ Frit 11 Glass } & \multicolumn{3}{|c|}{ Frit 12 Glass } \\
\hline & Target & Meas. & $\%$ Diff. & Target & Meas. & $\%$ Diff. & Target & Meas. & $\%$ Diff. & Target & Meas. & $\%$ Diff. \\
\hline $\mathrm{Al}_{2} \mathrm{O}_{3}$ & 9.59 & 9.45 & -1.43 & 9.59 & 9.01 & -6.05 & 9.59 & 9.21 & -3.96 & 9.59 & 9.21 & -3.92 \\
\hline $\mathrm{B}_{2} \mathrm{O}_{3}$ & 6.96 & 6.92 & -0.48 & 6.96 & 6.97 & 0.21 & 9.41 & 8.15 & -13.38 & 9.41 & 8.15 & -13.38 \\
\hline $\mathrm{BaO}$ & 0.09 & 0.07 & -21.15 & 0.09 & 0.07 & -25.15 & 0.09 & 0.07 & -21.80 & 0.09 & 0.06 & -25.93 \\
\hline $\mathrm{CaO}$ & 1.09 & 1.17 & 7.10 & 1.09 & 1.09 & 0.08 & 1.09 & 1.17 & 7.61 & 1.09 & 1.29 & 17.94 \\
\hline $\mathrm{Ce}_{2} \mathrm{O}_{3}$ & 0.23 & 0.72 & 215.75 & 0.23 & 0.72 & 214.14 & 0.23 & 0.76 & 231.54 & 0.23 & 0.69 & 202.51 \\
\hline $\mathrm{Cr}_{2} \mathrm{O}_{3}$ & 0.11 & 0.19 & 67.36 & 0.11 & 0.17 & 51.20 & 0.11 & 0.20 & 75.17 & 0.11 & 0.17 & 53.09 \\
\hline $\mathrm{CuO}$ & 4.09 & 2.70 & -33.95 & 0.03 & 0.04 & 33.27 & 3.91 & 3.95 & 1.07 & 0.03 & 0.06 & 69.72 \\
\hline $\mathrm{Fe}_{2} \mathrm{O}_{3}$ & 12.79 & 12.74 & -0.40 & 12.79 & 11.99 & -6.25 & 12.79 & 12.08 & -5.51 & 12.79 & 11.46 & -10.39 \\
\hline $\mathrm{K}_{2} \mathrm{O}$ & 0.07 & 0.05 & -26.75 & 0.07 & 0.05 & -34.22 & 0.07 & 0.03 & -55.02 & 0.07 & 0.04 & -44.58 \\
\hline $\mathrm{La}_{2} \mathrm{O}_{3}$ & 0.08 & 0.00 & -100.00 & 0.08 & 0.00 & -100.00 & 0.08 & 0.00 & -100.00 & 0.08 & 0.00 & -100.00 \\
\hline $\mathrm{Li}_{2} \mathrm{O}$ & 4.64 & 4.32 & -6.82 & 4.64 & 4.48 & -3.37 & 4.43 & 4.29 & -3.13 & 4.43 & 4.35 & -1.74 \\
\hline $\mathrm{MgO}$ & 0.17 & 0.15 & -11.47 & 0.17 & 0.15 & -12.45 & 0.17 & 0.14 & -16.64 & 0.17 & 0.15 & -14.69 \\
\hline $\mathrm{MnO}$ & 1.66 & 1.68 & 1.11 & 5.71 & 3.80 & -33.43 & 1.66 & 1.42 & -14.44 & 5.54 & 4.78 & -13.69 \\
\hline $\mathrm{Na}_{2} \mathrm{O}$ & 12.46 & 13.22 & 6.07 & 12.46 & 13.00 & 4.37 & 12.29 & 12.65 & 2.98 & 12.29 & 12.67 & 3.11 \\
\hline $\mathrm{NiO}$ & 0.48 & 0.61 & 27.10 & 0.48 & 0.53 & 9.17 & 0.48 & 0.58 & 20.42 & 0.48 & 0.55 & 13.62 \\
\hline $\mathrm{PbO}$ & 0.10 & 0.08 & -23.60 & 0.10 & 0.08 & -21.88 & 0.10 & 0.08 & -23.40 & 0.10 & 0.07 & -29.38 \\
\hline $\mathrm{SO}_{4}$ & 0.08 & 0.27 & 221.12 & 0.08 & 0.26 & 207.75 & 0.08 & 0.30 & 257.99 & 0.08 & 0.29 & 254.92 \\
\hline $\mathrm{SiO}_{2}$ & 43.69 & 42.49 & -2.74 & 43.69 & 43.97 & 0.64 & 41.80 & 41.79 & -0.02 & 41.80 & 42.67 & 2.08 \\
\hline $\mathrm{TiO}_{2}$ & 1.37 & 1.22 & -10.88 & 1.37 & 1.15 & -15.86 & 1.37 & 1.21 & -11.19 & 1.37 & 1.16 & -15.21 \\
\hline $\mathrm{ZnO}$ & 0.05 & 0.09 & 60.42 & 0.05 & 0.06 & 7.21 & 0.05 & 0.07 & 28.36 & 0.05 & 0.07 & 21.46 \\
\hline $\mathrm{ZrO}_{2}$ & 0.21 & 0.22 & 7.08 & 0.21 & 0.20 & -3.49 & 0.21 & 0.21 & -0.69 & 0.21 & 0.20 & -4.17 \\
\hline
\end{tabular}




\subsection{XRD Results}

The XRD results for the quenched and CCC versions of the study glasses are shown in Table 3-2. All of the quenched glasses were XRD amorphous. Magnetite and trevorite were identified in the CCC versions of the glasses made with Frits 4 and 12 . These crystalline phases will not likely impact the durability of the glass.

Table 3-2. XRD Results for the Study Glasses.

\begin{tabular}{||c|c|c|}
\hline Glass ID & Heat Treatment & XRD Results \\
\hline \multirow{2}{*}{ Frit 4 Glass } & Quenched & Amorphous \\
\cline { 2 - 3 } & CCC & Magnetite and Trevorite \\
\hline Frit 5 Glass & Quenched & Amorphous \\
\hline Frit 11 Glass & Quenched & Amorphous \\
\hline \multirow{2}{*}{ Frit 12 Glass } & Quenched & Amorphous \\
\cline { 2 - 3 } & CCC & Magnetite and Trevorite \\
\hline
\end{tabular}

\subsection{PCT Results}

The PCT results for the study glasses are listed in Table 3-3. A review of the data showed no issues with the blank vessels, no issues with the ARM reference glass, no water loss issues, and no issues with the surface to volume ratios of the study glasses. The PCT values are normalized based on the measured glass compositions. The durabilities of the study glasses are considerably better than that of the EA reference glass. No significant impact of heat treatment is seen for the glasses made with Frits 4 and 12, and the crystalline phases identified in the CCC glasses had no significant impact on durability. The PCT values are very similar among all of the study glasses, indicating that the four different frit compositions had minimal impact on the durability of the glass products.

Table 3-3. PCT Results for the Study Glasses and EA.

\begin{tabular}{|c|c|c|c|c|c|}
\hline \multirow{2}{*}{ Glass ID } & $\begin{array}{c}\text { Heat } \\
\text { Treatment }\end{array}$ & NL [B] (g/L) & NL [Li] (g/L) & NL [Na] (g/L) & NL [Si] (g/L) \\
\hline EA & n/a & 15.44 & 8.81 & 11.88 & 3.66 \\
\hline \multirow{2}{*}{ Frit 4 Glass } & Quenched & 0.77 & 0.85 & 0.74 & 0.48 \\
\cline { 2 - 6 } & CCC & 0.65 & 0.79 & 0.69 & 0.48 \\
\hline Frit 5 Glass & Quenched & 0.67 & 0.78 & 0.66 & 0.46 \\
\hline Frit 11 Glass & Quenched & 0.73 & 0.83 & 0.66 & 0.46 \\
\hline \multirow{2}{*}{ Frit 12 Glass } & Quenched & 0.83 & 0.88 & 0.74 & 0.46 \\
\cline { 2 - 6 } & CCC & 0.74 & 1.16 & 0.80 & 0.52 \\
\hline \hline
\end{tabular}

\subsection{Summary}

The complete report from KRI is included as Appendix A. A summary of the melt rate data, including a previous experiment using Frit 550 without additives, is provided in Table 4-1. Briefly, the results of the melt rate testing in the SMK melter showed that the feed rate could be significantly increased (while maintaining the same amount of cold cap coverage) when $\mathrm{MnO}$ or $\mathrm{CuO}$ were added to Frit 550 with the SMR-2 sludge. The feed rates increased by about $26 \%$ when $\mathrm{CuO}$ was added to the frit and by about $27 \%$ when $\mathrm{MnO}$ was added to the frit, as compared to earlier results for Frit 550 alone. The impact of adding additional $\mathrm{B}_{2} \mathrm{O}_{3}$ to the frit was minor 
when added with $\mathrm{CuO}$ (Frit 11). The additional $\mathrm{B}_{2} \mathrm{O}_{3}$ showed a more significant, 39\% improvement in melt rate when added with $\mathrm{MnO}$ (Frit 12). The additional $\mathrm{B}_{2} \mathrm{O}_{3}$ also reduced the viscosity of the glasses during pouring. Some differences in the amount of time necessary for consumption of the cold cap after the completion of feeding were noted, but were considered insignificant.

Table 4-1. Results of Melt Rate Testing with Frits Containing Additives.

\begin{tabular}{|c|c|c|c|c||}
\hline $\begin{array}{c}\text { Frit } \\
\text { Composition }\end{array}$ & $\begin{array}{c}\text { Feed Solids } \\
\text { Loading } \\
\left(\mathbf{g} / \mathbf{c m}^{\mathbf{3}}\right)\end{array}$ & $\begin{array}{c}\text { Feed Rate to Maintain } \\
\mathbf{9 0 \%} \text { Cold Cap Coverage } \\
\text { (g/min) }\end{array}$ & $\begin{array}{c}\text { Percent } \\
\text { Improvement } \\
\text { in Feed Rate }\end{array}$ & $\begin{array}{c}\text { Cold Cap } \\
\text { Consumption After } \\
\text { Feeding } \\
\text { (seconds) }\end{array}$ \\
\hline $\begin{array}{c}\text { Frit 1 } \\
\text { (Frit 550) }\end{array}$ & 0.28 & 7.0 & - & 547 \\
\hline $\begin{array}{c}\text { Frit 4 } \\
(\text { Frit 550 }+\mathrm{CuO})\end{array}$ & 0.29 & 8.8 & $26 \%$ & 562 \\
\hline $\begin{array}{c}\text { Frit 5 } \\
(\text { Frit 550 }+\mathrm{MnO})\end{array}$ & 0.29 & 8.9 & $27 \%$ & 516 \\
\hline $\begin{array}{c}\text { Frit } 11 \\
(\text { Frit } 550+ \\
\left.\text { CuO }+\mathrm{B}_{2} \mathrm{O}_{3}\right)\end{array}$ & 0.29 & 8.8 & $26 \%$ & 538 \\
\hline $\begin{array}{c}\text { Frit } 12 \\
(\text { Frit } 550+ \\
\left.\mathrm{MnO}+\mathrm{B}_{2} \mathrm{O}_{3}\right)\end{array}$ & 0.29 & 9.7 & $39 \%$ & 501 \\
\hline
\end{tabular}

Samples of the glasses from the melt rate testing characterized at SRNL showed that there were no significant impacts on crystallization of the glasses. All of the glasses had very good chemical durability. Chemical composition measurements showed that the frit additives were present in concentrations below the targeted values in some of the glasses. Therefore, it is possible that higher concentrations of these additives may further improve melt rate, although the impacts of higher concentrations of these components on crystallization and durability would need to be determined. Overall, the results show an excellent potential for these additives to significantly improve waste throughput for DOE vitrification facilities.

Future experiments should investigate the impacts of these frit additives on melt rate for lower aluminum concentration sludges (i.e., wastes treated with the aluminum dissolution process), and for higher $\mathrm{TiO}_{2}$ concentration sludges (i.e., wastes containing streams from the small column ion exchange process). The impacts of the frit additives on the liquidus temperature and the viscosity of the glasses should also be determined.

\subsection{References}

1. Newell, J. D., T. B. Edwards and D. K. Peeler, "Initial MAR Assessments to Assess the Impact of Al-dissolution on DWPF Operating Windows," U.S. Department of Energy Report WSRC-STI-2007-00688, Revision 0, Washington Savannah River Company, Aiken, SC (2007).

2. Stone, M. E., "Savannah River Site Simulant Sludge Compositions and Preparation Instructions for SMK Melter Testing - SMR-2," U.S. Department of Energy Memorandum SRNLL3100-2008-00080, Savannah River National Laboratory, Aiken, SC (2008). 
3. Marra, S. L. and C. M. Jantzen, "Characterization of Projected DWPF Glass Heat Treated to Simulate Canister Centerline Cooling," U.S. Department of Energy Report WSRC-TR-92-142, Revision 1, Westinghouse Savannah River Company, Aiken, SC (1993).

4. ASTM, "Standard Test Methods for Determining Chemical Durability of Nuclear Waste Glasses: The Product Consistency Test (PCT)," ASTM C-1285, (2002).

5. Jantzen, C. M., N. E. Bibler, D. C. Beam, C. L. Crawford and M. A. Pickett, "Characterization of the Defense Waste Processing Facility (DWPF) Environmental Assessment (EA) Glass Standard Reference Material," U.S. Department of Energy Report WSRC-TR-92-346, Revision 1, Westinghouse Savannah River Company, Aiken, SC (1993).

6. Jantzen, C. M., J. B. Picket, K. G. Brown, T. B. Edwards and D. C. Beam, "Process/Product Models for the Defense Waste Processing Facility (DWPF): Part I. Predicting Glass Durability from Composition Using a Thermodynamic Hydration Energy Reaction Model (THERMO)," U.S. Department of Energy Report WSRC-TR-93-672, Revision 1, Westinghouse Savannah River Company, Aiken, SC (1995). 
SRNL-STI-2010-00811

Revision 0

Appendix A. Final Report from KRI on the Impacts of Frit Additives for Melt Rate Improvement 
Earlier, under Task 1D-1, KRI made an assessment regarding the selection of additives for the glass frits, taking into account empirical coefficients that included the meltability factor. During the discussions of the summary table, KRI and SRNL agreed on conducting four experiments with the SMR-2 sludge simulant and Frit 550 containing the following additives: 1) $\mathrm{MnO}$; 2) $\mathrm{MnO}+\mathrm{B}_{2} \mathrm{O}_{3}$; 3) $\mathrm{CuO}$; 4) $\mathrm{CuO}+\mathrm{B}_{2} \mathrm{O}_{3}$. The sludge simulant was prepared according to the procedure entitled: Savanna River Site Simulant Sludge Compositions and Preparation Instructions for SMK Melter Testing - SMR-2. The frits with the additives were melted in Pt boats and crushed to particulates ranging from 74 to $177 \mu \mathrm{m}$.

\section{Fabrication of the Sludge-Slurry ${ }^{\mathrm{a}}$ Feed Simulant SMR-2}

Under Task 1D-1, KRI prepared the SMR-2 simulant using the procedure entitled: Savannah River Site Simulant Sludge Compositions and Preparation Instructions for SMK Melter Testing - SMR-2.

Four batches were prepared, specifically, SMR-2-1, SMR-2-2, SMR-2-3, and SMR-2-4. Each of the batches was calculated for the targeted volume of the sludge, i.e., 3L. Each batch was prepared in a cylindrical plastic vessel with the diameter of $16.7 \mathrm{~cm}$. Table 1 shows quantities of the input chemicals added at various phases of the procedure to obtain the baseline batch of the final sludge-slurry product.

Table 1. Preparation of SMR-2 Sludge-Slurry Simulant

\begin{tabular}{|c|c|}
\hline \multicolumn{2}{|c|}{ Phase 1, Steps 1-7: Precipitation of the Hydroxo-Carbonate Precipitate } \\
\hline Added Chemical & g \\
\hline $\mathrm{KMnO}_{4}$ & 13.25 \\
\hline $\mathrm{Mn}\left(\mathrm{NO}_{3}\right)_{2} \cdot 6 \mathrm{H}_{2} \mathrm{O}$ & 36.38 \\
\hline $\mathrm{Fe}\left(\mathrm{NO}_{3}\right)_{3} \cdot 9 \mathrm{H}_{2} \mathrm{O}$ & 711.74 \\
\hline $\mathrm{Ni}\left(\mathrm{NO}_{3}\right)_{2} \cdot 6 \mathrm{H}_{2} \mathrm{O}$ & 20.50 \\
\hline $\mathrm{NaOH}$ & 238.80 \\
\hline $\mathrm{CaCO}_{3}$ & 21.44 \\
\hline \multicolumn{2}{|c|}{$\begin{array}{l}\text { Phase 3, Steps1-4: Washing the Slurry Prepared in Phase } 1 \\
\text {--slurries generated in Phase } 1 \text { were washed with inhibited water with the } \\
\pm 0.25 \text { containing equimolar quantities of } \mathrm{NaOH} \text { and } \mathrm{NaNO}_{2} \text {. The washing } \\
\text { until the content of soluble salts in the supernates decreased to } 0.15-0.20 \\
\text { time for settling the precipitates between the washings was at least } 24\end{array}$} \\
\hline
\end{tabular}

\footnotetext{
a Translator's Note. The term "sludge-slurry" was proposed by KRI.
} 


\section{Phase 4, Steps 1-2: Quantity of Chemicals to be Added During Phase 4}

The following changes were introduced into the procedure entitled: SRS Simulant Sludge Compositions and Preparation Instructions for SMK Melter Testing - SMR-2 at this phase:

- Since $\mathrm{NaAlO}_{2}$ was not commercially available, the following (6.50 g) was used for its replacement:

$\mathrm{Al}\left(\mathrm{NO}_{3}\right)_{3} \cdot 9 \mathrm{H}_{2} \mathrm{O}(29.75 \mathrm{~g})+4 \mathrm{NaOH}(12.69 \mathrm{~g}) \rightarrow \mathrm{NaAlO}_{2}(6.50 \mathrm{~g})+3 \mathrm{NaNO}_{3}(20.22$

g) $+11 \mathrm{H}_{2} \mathrm{O}$

with an appropriate adjustment of the $\mathrm{NaOH}$ and $\mathrm{NaNO}_{3}$ quantities stated in the Procedure. Prior to this, $\mathrm{Al}\left(\mathrm{NO}_{3}\right)_{3} \cdot 9 \mathrm{H}_{2} \mathrm{O}$ and $\mathrm{NaOH}$ were dissolved in a separate vessel, the solutions were combined and mixed until the generated $\mathrm{Al}(\mathrm{OH})_{3}$ fully dissolved. The obtained solution was introduced into the working vessel.

- Instead of $\mathrm{MgO}, 4 \mathrm{MgCO}_{3} \cdot \mathrm{Mg}(\mathrm{OH})_{2} \cdot 4 \mathrm{H}_{2} \mathrm{O}(43.77 \% \mathrm{MgO})$ was used.

\begin{tabular}{|c|c|}
\hline $\begin{array}{l}\text { Added Chemical (in the sequence of } \\
\text { addition) }\end{array}$ & g \\
\hline $\mathrm{Al}\left(\mathrm{NO}_{3}\right)_{3} \cdot 9 \mathrm{H}_{2} \mathrm{O}$ & 29.75 \\
\hline $\mathrm{NaOH}$ & $36.59+12.69=49.28$ \\
\hline $\mathrm{Al}(\mathrm{OH})_{3}$ & 155 \\
\hline $\mathrm{BaO}$ & 0.99 \\
\hline $\mathrm{CeO}_{2}$ & 6.65 \\
\hline $\mathrm{Cr}_{2} \mathrm{O}_{3}$ & 1.22 \\
\hline $\mathrm{CuO}$ & 0.39 \\
\hline $\mathrm{KOH}$ & 0.98 \\
\hline $\mathrm{MgO}$ & 1.92 \\
\hline $\mathrm{Na}_{2} \mathrm{CO}_{3} \cdot 2 \mathrm{H}_{2} \mathrm{O}$ & 8.15 \\
\hline $\mathrm{Na}_{2} \mathrm{C}_{2} \mathrm{O}_{4}$ & 4.72 \\
\hline $\mathrm{Na}_{2} \mathrm{SO}_{4}$ & 1.61 \\
\hline $\mathrm{Na}_{3} \mathrm{PO}_{4}$ & 1.16 \\
\hline $\mathrm{NaCl}$ & 6.11 \\
\hline $\mathrm{NaF}$ & 0.13 \\
\hline $\mathrm{NaNO}_{2}$ & 77.99 \\
\hline $\mathrm{NaNO}_{3}$ & $49.29-20.22=29.07$ \\
\hline $\mathrm{PbO}$ & 1.07 \\
\hline $\mathrm{SiO}_{2}$ & 15.35 \\
\hline $\mathrm{TiO}_{2}$ & 15.03 \\
\hline $\mathrm{ZnO}$ & 0.59 \\
\hline $\mathrm{ZrO}_{2}$ & 2.33 \\
\hline
\end{tabular}

During the washing cycle, the time for settling of the last $\left(11^{\text {th }}\right.$ batch $)$ batch of the wash water was 72 hours. The volumes of the washed hydroxide sludges varied, specifically: Vessel \# 1 - about 3 L, Vessel \# 1 - about 3 L, Vessel \# 2 and Vessel \# 4 - less than 3 L.

The masses of the final waste simulant product were as follows: 
\# 1 - 3,637 g;

\# $2-3,425 \mathrm{~g}$;

\# 3 - 3,850 g;

\# 4 - 3,429 g.

To normalize the startup conditions of the glass melting, the sludge simulants in Vesel \# 1, Vessel \# 2, and Vessel \# 4 were diluted with de-ionized water to 3,850 g.

After the sludge simulants were mixed, their densities were measured in each vessel. Table 2 contains parameters of the final sludge simulants for all four vessels.

Table 2. Parameters of the Final Sludge Simulants

\begin{tabular}{|l|c|}
\hline Waste mass & $3850 \mathrm{~g}$ \\
\hline Waste density & $1.08 \mathrm{~g} / \mathrm{cm}^{3}$ \\
\hline Estimated waste volume & $3565 \mathrm{~cm}^{3}$ \\
\hline Estimated oxide content & $423.74 \mathrm{~g}$ \\
\hline
\end{tabular}

The estimated compositions of the SMR-2 sludge simulant (on the calcinate oxide basis) is shown in Table 3.

Table 3. Estimated Composition of the SMR-2 Sludge Simulant

\begin{tabular}{|c|c|c|}
\hline Oxide & $\mathrm{g} / 3 \mathrm{~L}$ of the targeted slurry & $\mathrm{wt} \%$ \\
\hline $\mathrm{MnO}_{2}$ & 18.21 & 4.30 \\
\hline $\mathrm{Fe}_{2} \mathrm{O}_{3}$ & 140.67 & 33.20 \\
\hline $\mathrm{NiO}$ & 5.28 & 1.25 \\
\hline $\mathrm{CaO}$ & 12.00 & 2.84 \\
\hline $\mathrm{Na}_{2} \mathrm{O}$ & 94.26 & 22.24 \\
\hline $\mathrm{Al}_{2} \mathrm{O}_{3}$ & 105.57 & 24.91 \\
\hline $\mathrm{BaO}$ & 0.99 & 0.23 \\
\hline $\mathrm{CeO}_{2}$ & 6.66 & 1.57 \\
\hline $\mathrm{Cr}_{2} \mathrm{O}_{3}$ & 1.23 & 0.29 \\
\hline $\mathrm{CuO}$ & 0.39 & 0.09 \\
\hline $\mathrm{K}_{2} \mathrm{O}$ & 0.81 & 0.19 \\
\hline $\mathrm{MgO}$ & 1.92 & 0.45 \\
\hline $\mathrm{PbO}_{\mathrm{SiO}}$ & 1.08 & 0.25 \\
\hline $\mathrm{TiO}_{2}$ & 15.36 & 3.62 \\
\hline $\mathrm{ZnO}_{\mathrm{ZrO}}$ & 15.03 & 3.55 \\
\hline $\mathrm{SO}_{3}$ & 0.60 & 0.14 \\
\hline $\mathrm{P}_{2} \mathrm{O}_{5}$ & 2.34 & 0.55 \\
\hline & 0.90 & 0.21 \\
\hline & 0.51 & 0.12 \\
\hline
\end{tabular}


SRNL-STI-2010-00811

Revision 0

The synthesis of the sludge simulants was followed by introducing additives into the frits and vitrification.

\section{Fabrication of Frits with Additives for Vitrification of SMR-2 Sludge Simulant}

Table 4 contains the frit compositions.

Table 4. Compositions of Frits with Oxides of Boron, Copper, and Manganese Added (mass\%)

\begin{tabular}{|c|c|c|c|c|c|c|}
\hline Frit \# & $\mathrm{B}_{2} \mathrm{O}_{3}$ & $\mathrm{Li}_{2} \mathrm{O}$ & $\mathrm{Na}_{2} \mathrm{O}$ & $\mathrm{SiO}_{2}$ & $\mathrm{CuO}$ & $\mathrm{MnO}$ \\
\hline 1 & 11.22 & 7.48 & 6.54 & 68.22 & 6.54 & - \\
\hline 2 & 11.22 & 7.48 & 6.54 & 68.22 & & 6.54 \\
\hline 3 & 15.17 & 7.14 & 6.25 & 65.18 & 6.25 & - \\
\hline 4 & 15.17 & 7.14 & 6.25 & 65.18 & - & 6.25 \\
\hline
\end{tabular}

The frit was made out of a batch containing such weighed chemicals as boric acid, lithium carbonate, sodium carbonate, silica, copper oxide and manganese oxide. The silica particle size did not exceed $120 \mu \mathrm{m}$ (certified chemical).

The batch was prepared by a thorough mixing of the appropriately rationed input components. The batch was divided into $200-250$ g portions of the glass frits to be placed into Pt boats and heated in the muffle furnace up to $1200^{\circ} \mathrm{C}$ with the holding time of 1.5 hours. Upon completion of the isothermal holding, the molten glass was poured onto a stainless steel plate for quenching.

The molten glass was crushed and ground using a vibration mill (VKMD model). The crushed frit was sieved manually using sieves with $160 \mu \mathrm{m}$ and $71 \mu \mathrm{m}$ diameters of cells (models s12/38 and s20/38 manufactured by Vibrotekhnik Company, Russia), with larger and smaller fractions sorted out and excluded.

The obtained glass frit samples were analyzed using the XRD method. According to the $\mathrm{XRD}$, the frits appeared to be X-ray amorphous formations.

The sludge simulant and the frit were mixed in the feed tank immediately before the feeding started. The mixture was fed onto the melt surface through a water-cooled feeder using a peristaltic pump.

Four thermocouples monitored the thermal mode of the system. The locations of the thermocouples are shown in Figs. 2, 3, 4, and 5.

As the startup material, KRI utilized earlier synthesized crushed glass (SMR-2 + "550") in Experiment \# 1 (SMR-2 + "550" + MnO) and Experiment \# 3 (SMR-2 + "550" + 
$\mathrm{CuO})$. Experiments \# $2\left(\mathrm{SMR}-2+\right.$ "550" $\left.+\mathrm{MnO}+\mathrm{B}_{2} \mathrm{O}_{3}\right)$ and \# 4 (SMR-2 + "550" + $\mathrm{CuO}+\mathrm{B}_{2} \mathrm{O}_{3}$ ) utilized the glasses generated in Experiments \# 1 and \# 3 . In all experiments, the startup loads resulted in approximately $3 \mathrm{~cm}$ deep startup melt layer on the bottom of the crucible melter. The small amount of the startup melt resulted in a temperature decrease in the area of the TC-1 thermocouple (in the area of the main latch rod located $\sim 2 \mathrm{~cm}$ away from the crucible bottom) upon feeding of the first portions of the batch onto the melt surface (see Figs. 2, 3, 4, and 5). As the melt layer grew thicker in the process of generation of new portions of glass, temperature fluctuations in the TC-1 thermocouple area significantly decreased. The sludge simulant feed rates were recorded upon feeding the third and the fourth portions of the sludge simulant.

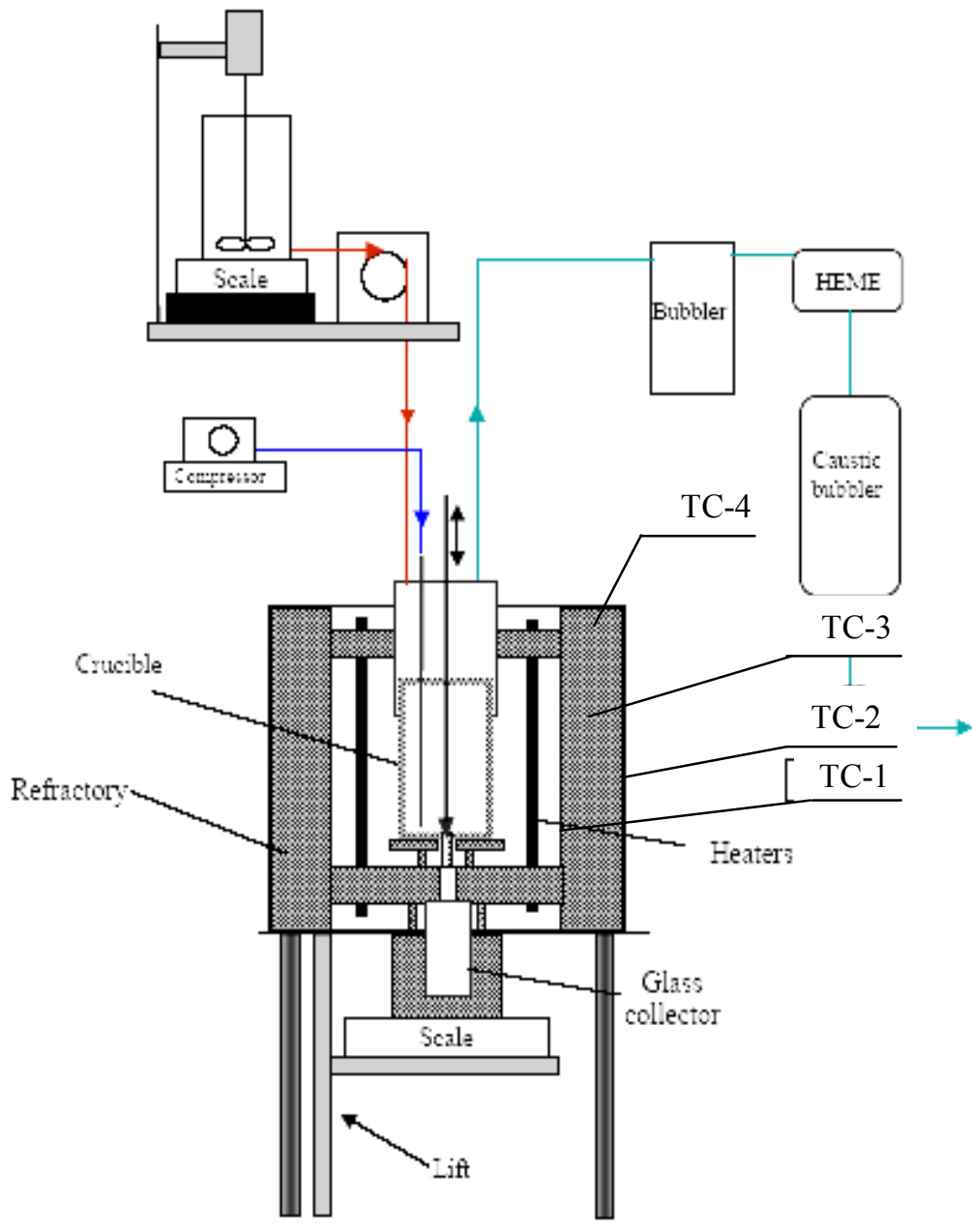

Fig.1. Layout of the Thermocouples in the SMK Crucible syscem
TC-1 in the main latch rod $(20 \mathrm{~mm}$ away from the crucible bottom)

TC-2 Outside wall of the crucible (in the area of the heaters)

TC-3 Above the melt

TC-4 Off-gases (at the inlet of the chiller of the off-gas system) 
SRNL-STI-2010-00811

Revision 0

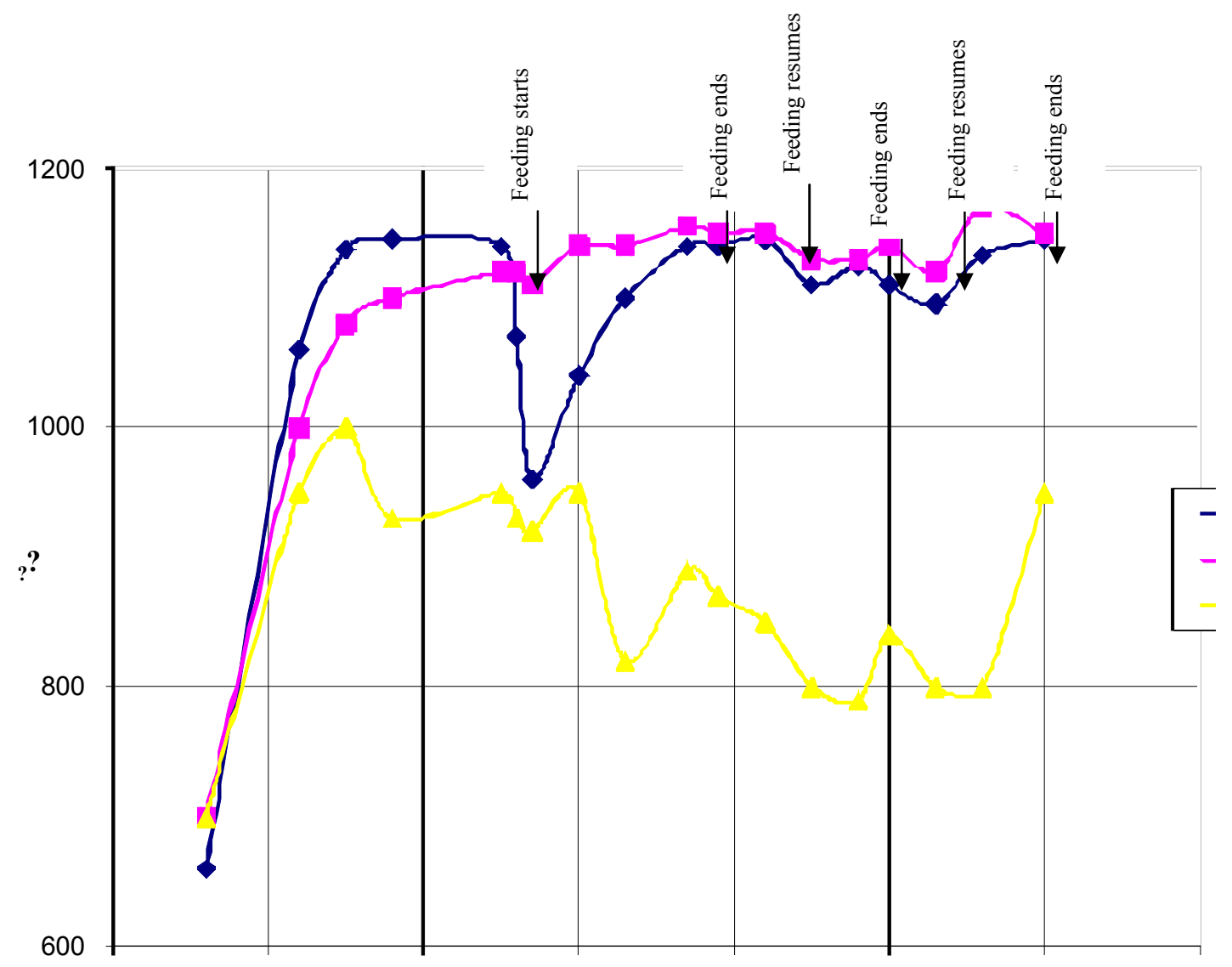

Fig. 2 


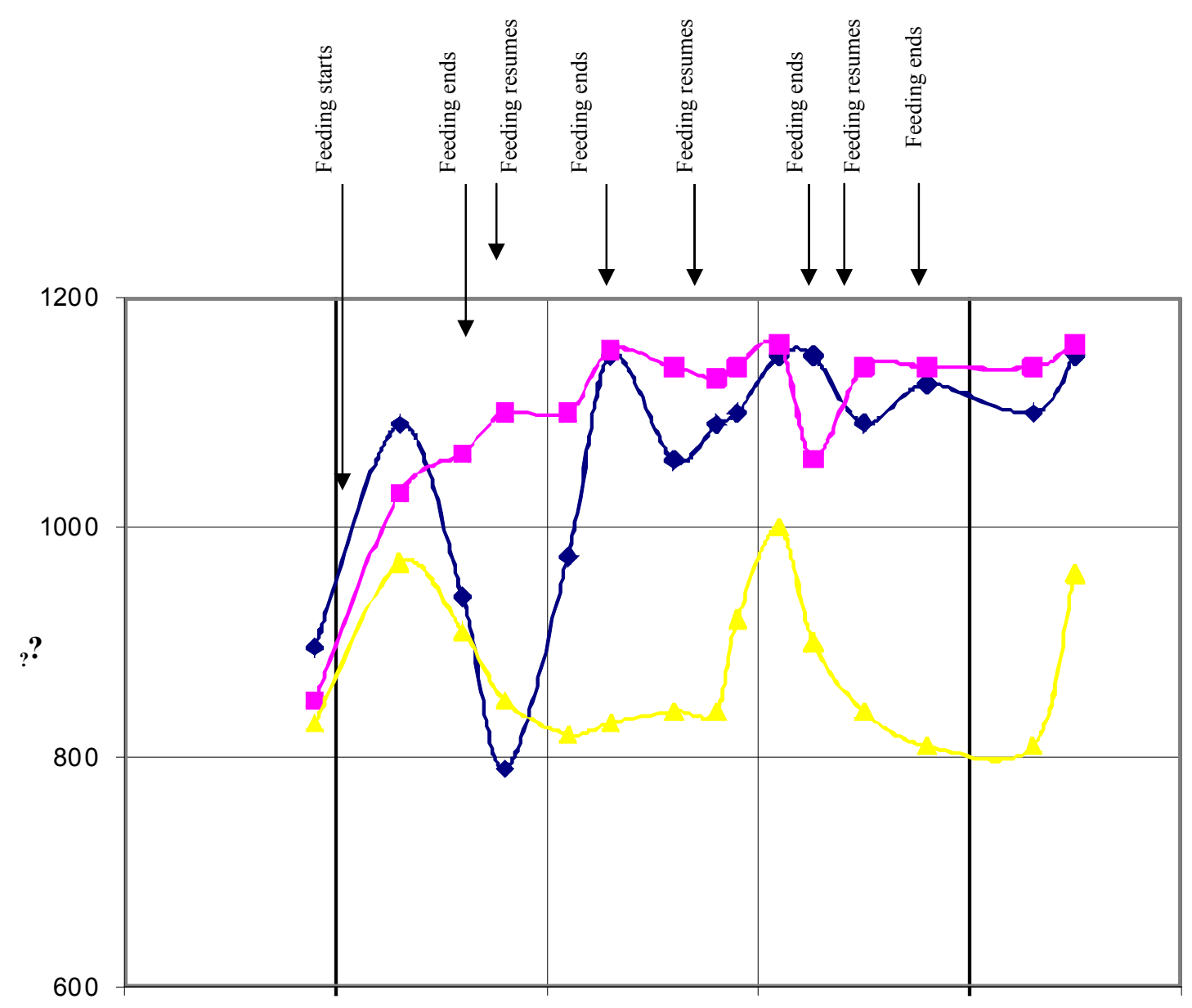

Fig. 3 
SRNL-STI-2010-00811

Revision 0

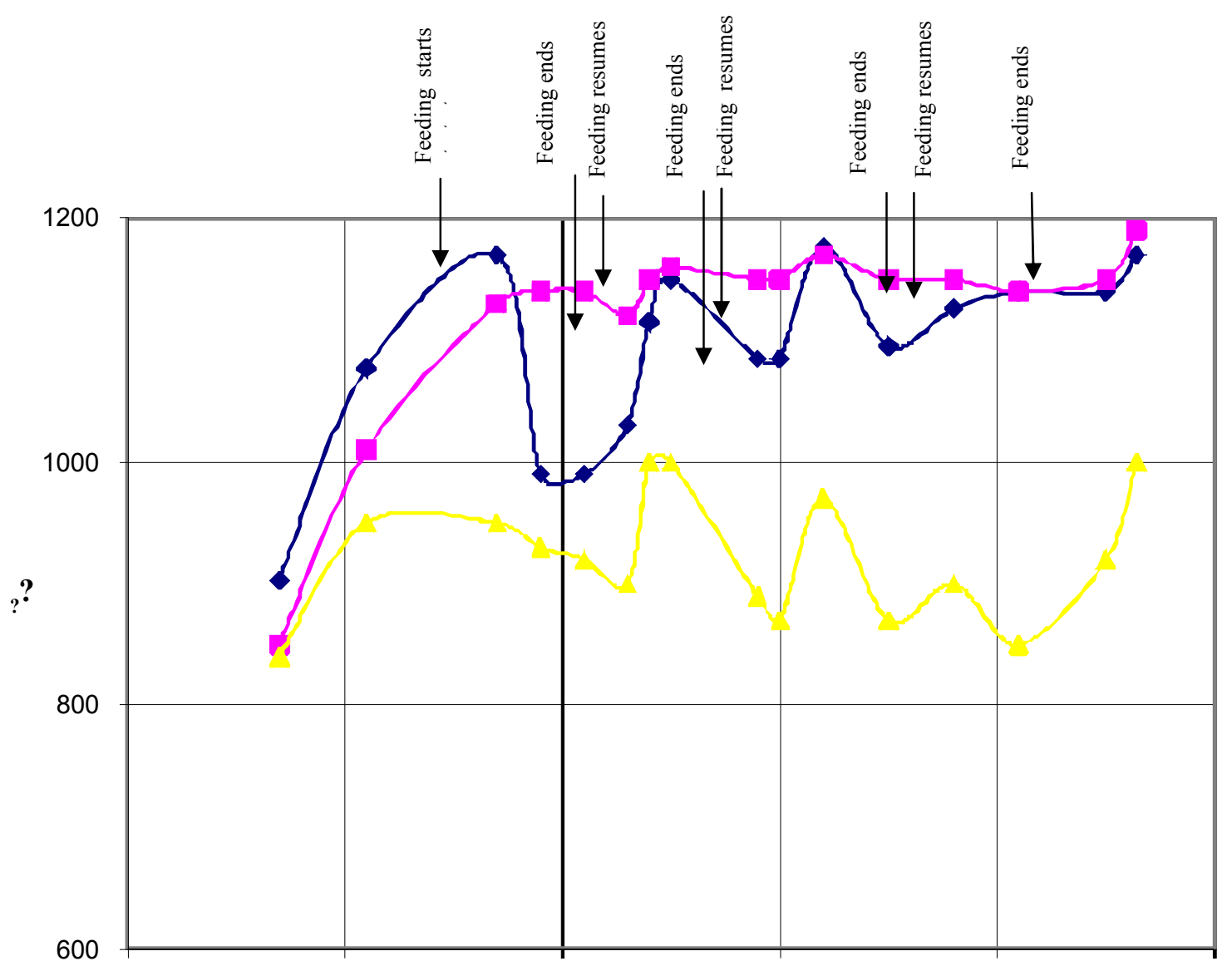

Fig. 4 
SRNL-STI-2010-00811

Revision 0

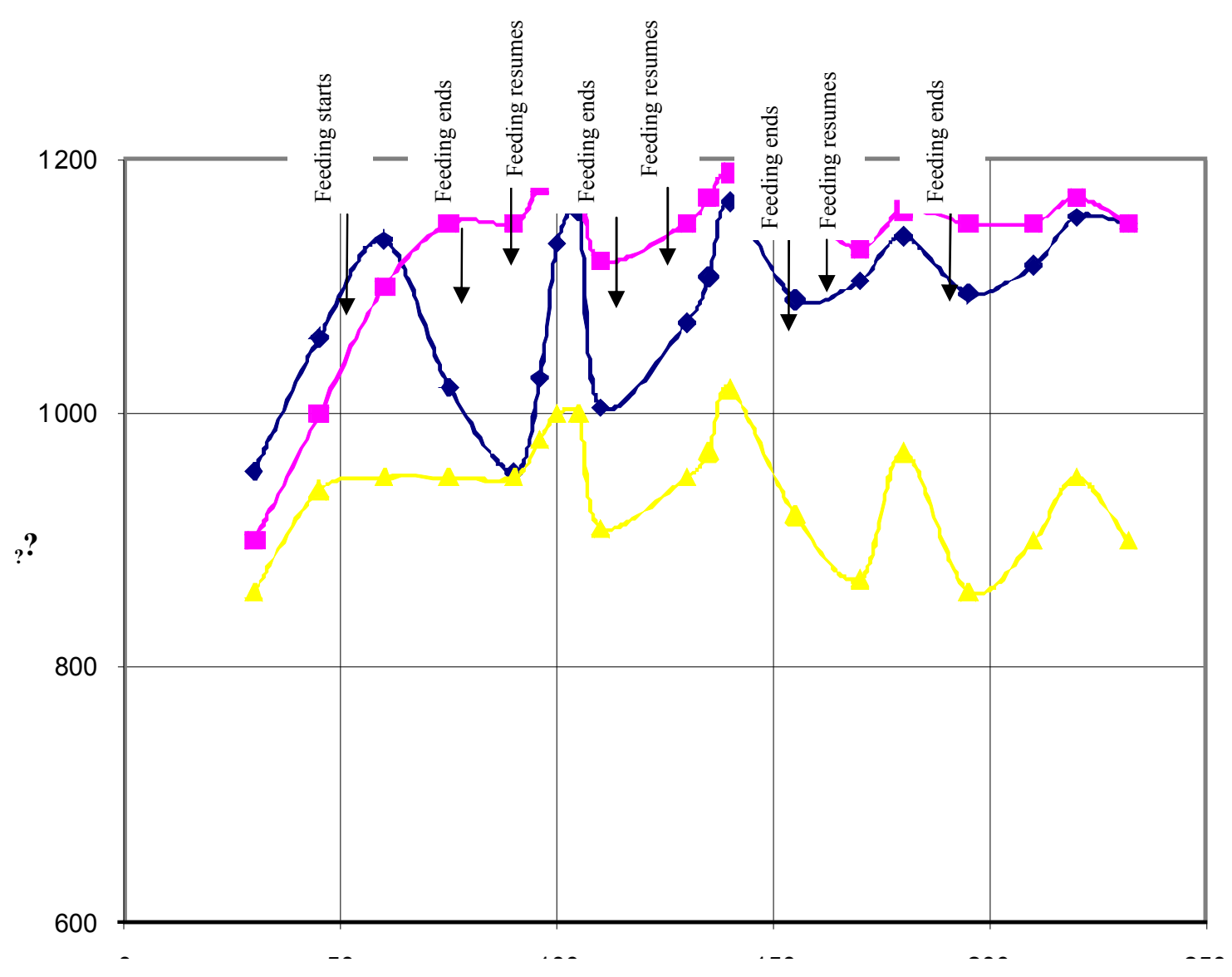

Fig. 5

The melt rate was selected by identifying the feed rate required to provide for $90 \%$ coverage of the cold cap by the melt surface and time required for consumption of the cold cap after the feeding was complete. The time required for consumption of the cold caps was measured upon completion of feeding of each four portions of the sludge simulant. The formation and consumption of the cold cap were visually monitored. While the cold cap was being generated, the sludge simulant distributed unevenly on the melt surface, mounding on the cold cap, with the top of the mound shifted towards the back wall of the crucible in the feed zone. The mounding made it difficult to measure the time required for the cold cap consumption because, with the visual assessments of the cold cap coverage, it was hard to determine the actual depth of the mounded layer. 
Table 5. SMR-2 Experiments Using the SMK System

\begin{tabular}{|c|c|c|c|c|c|c|c|c|c|c|c|}
\hline \# & $\begin{array}{c}\text { Frit, } \\
\text { waste }\end{array}$ & $\begin{array}{c}\text { Sludge } \\
\text { simulant } \\
\text { (waste); } \\
+ \\
\text { washed } \\
\text { products; } \\
\text { Total } \\
\left(\mathrm{cm}^{3}\right)\end{array}$ & $\begin{array}{c}\text { Eoxides } \\
\text { in the } \\
\text { waste } \\
\text { sludge } \\
\text { simulant } \\
(\mathrm{g})\end{array}$ & 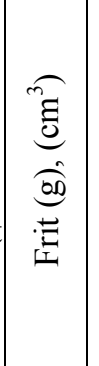 & $\begin{array}{c}\Sigma \text { oxides }+ \text { frit } \\
(\mathrm{g}) \\
\left(\mathrm{cm}^{3}\right)\end{array}$ & 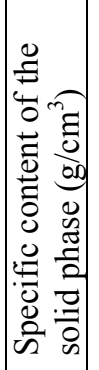 & $\begin{array}{c}\text { Feed rate } \\
(\mathrm{L} / \mathrm{hr}) \\
\left(\mathrm{cm}^{3} / \mathrm{min}\right) \\
(\mathrm{g} / \mathrm{min})\end{array}$ & $\begin{array}{c}\text { Specific } \\
\text { feeding } \\
\text { rate } \\
\left(\mathrm{g} / \mathrm{cm}^{2} * \mathrm{hr}\right)\end{array}$ & $\mid \begin{array}{c}\text { Cold cap } \\
\text { consumption } \\
\sim 90 \% \text { (sec) }\end{array}$ & $\begin{array}{l}\text { Pouring } \\
\text { (g/min) }\end{array}$ & 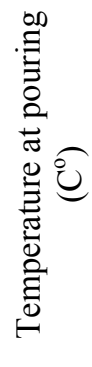 \\
\hline & $\begin{array}{r}\ll 50 » \\
\text { SMR-2 }\end{array}$ & $\begin{array}{r}3600 \\
+100 \\
3700 \\
\end{array}$ & 420.36 & $\begin{array}{c}685.8 \\
245\end{array}$ & $\begin{array}{c}1106.16 \\
3945\end{array}$ & 0.280 & $\begin{array}{c}1.5 \\
25.0 \\
7.000\end{array}$ & 6.774 & 547 & & \\
\hline 1 & $\begin{array}{c}\ll 550 » \\
\text { SMR-2- } \\
1 \\
\mathrm{MnO}\end{array}$ & 3600 & 423.74 & $\begin{array}{l}691 \\
261\end{array}$ & $\begin{array}{c}1114.7 \\
3861\end{array}$ & 0.289 & $\begin{array}{c}1.9 \\
30.8 \\
8.9\end{array}$ & 8.58 & 516 & 120 & 1150 \\
\hline 2 & $\begin{array}{c}\ll 550 » \\
\text { SMR-2- } \\
2 \\
\mathrm{MnO} \\
\mathrm{B}_{2} \mathrm{O}_{3} \\
\end{array}$ & 3565 & 423.74 & $\begin{array}{l}691 \\
261\end{array}$ & $\begin{array}{c}1114.7 \\
3826\end{array}$ & 0.292 & $\begin{array}{c}2.0 \\
33.3 \\
9.7\end{array}$ & 9.42 & 501 & 148 & 1150 \\
\hline 3 & $\begin{array}{c}\ll 550 » \\
\text { SMR-2- } \\
3 \\
\mathrm{CuO}\end{array}$ & 3565 & 423.74 & $\begin{array}{l}691 \\
261\end{array}$ & $\begin{array}{c}1114.7 \\
3826\end{array}$ & 0.292 & $\begin{array}{c}1.8 \\
30.0 \\
8.76\end{array}$ & 8.45 & 562 & 127 & 1150 \\
\hline 4 & $\begin{array}{c}\ll 550 » \\
\mathrm{SMR}-2- \\
4 \\
\mathrm{CuO} \\
\mathrm{B}_{2} \mathrm{O}_{3}\end{array}$ & 3565 & 423.74 & $\begin{array}{l}691 \\
261\end{array}$ & $\begin{array}{c}1114.7 \\
3826\end{array}$ & 0.292 & $\begin{array}{c}1.8 \\
30.0 \\
8.76\end{array}$ & 8.45 & 538 & 137,1 & 1150 \\
\hline
\end{tabular}

The results of the experimental runs are given in Table 5. For comparison, Table 5 also contains data on the previously performed experiment with SMR-2 sludge simulant (waste) and Frit 550 (no additives). Table 5 demonstrates the following:

1. Addition of $\mathrm{MnO}$ to Frit 550 makes it possible to increase the feed rate by $\sim 27 \%$, in comparison with the Frit $550+$ SMR-2 (no additives) combination; addition of MnO $+\mathrm{B}_{2} \mathrm{O}_{3}$ to Frit 550 increases the feed rate by $\sim 33 \%$.

2. Addition of $\mathrm{CuO}$ to Frit 550 increases the feed rate by $20 \%$; if $\mathrm{B}_{2} \mathrm{O}_{3}$ is added into the Frit $550+\mathrm{CuO}$ combination, the feed rate is not affected (in comparison with the Frit $550+\mathrm{CuO}$ combination).

3. The time required for consumption of the cold cap when it covers $90 \%$ of the melt surface slightly decreases if $\mathrm{MnO}$ is added to Frit 550 and slightly decreases if $\mathrm{CuO}$ is added to Frit 550 (in comparison with the experiment without additives to Frit 550). 
4. If $\mathrm{B}_{2} \mathrm{O}_{3}$ is added into the Frit $550+\mathrm{MnO}$ and Frit $550+\mathrm{CuO}$ combinations, the time required for the cold cap consumption slightly decreases.

5. Since the experiments generated the equal amounts of the molten glass $(\sim 10 \mathrm{~cm}$ deep layer in the crucible) and the pouring time was the same (498 seconds) at the same temperature $\left(1,150^{\circ} \mathrm{C}\right)$, the relative viscosity of the generated glasses can be compared. Table 5 shows that the pour rates increase (consequently, the viscosities decrease) in the following sequence: Experiment \# 1 (Frit $550+\mathrm{MnO}$ ), Experiment \# 3 (Frit $550+\mathrm{CuO}$ ), Experiment \# 4 (Frit $550+\mathrm{CuO}+\mathrm{B}_{2} \mathrm{O}_{3}$ ), Experiment \# 2 (Frit $\left.550+\mathrm{MnO}+\mathrm{B}_{2} \mathrm{O}_{3}\right)$. The difference between the pour rates in Experiment \# 1 and Experiment \# 3 is insignificant $(\sim 6 \%)$, the difference between the pour rates in Experiment \# 1 and Experiment \# 2 is $\sim 23 \%$, and the difference between the pour rates in Experiment \# 3 and Experiment \# 4 is $\sim 8 \%$. In other words, the pour rate increases by $\sim 6 \%$ if $\mathrm{CuO}$ is added to Frit 550 instead of $\mathrm{MnO}$. If $\mathrm{B}_{2} \mathrm{O}_{3}$ is added to the Frit $550+\mathrm{CuO}$ combination, the pour rate increases by $\sim 8 \%$, and if $\mathrm{B}_{2} \mathrm{O}_{3}$ is added to the Frit $550+\mathrm{MnO}$ combination, the pour rate increases by $\sim 23 \%$.

\section{Conclusions}

1. Addition of $\mathrm{MnO}$ and $\mathrm{CuO}$ to Frit 550 makes it possible to increase the feed rate of the fritted sludge simulant (SMR-2 + Frit $550+$ additives) by $\sim 27 \%$ and $\sim 20 \%$, respectively. If $\mathrm{B}_{2} \mathrm{O}_{3}$ is added to the Frit $550+\mathrm{MnO}$ combination, the feed rate increases by $\sim 6 \%$. If $\mathrm{B}_{2} \mathrm{O}_{3}$ is added to the Frit $550+\mathrm{CuO}$ combination, the feed rate does not change.

2. The additives do not significantly affect the time required for consumption of cold caps.

3. $\mathrm{B}_{2} \mathrm{O}_{3}$ additives to the Frit $550+\mathrm{MnO}$ and Frit $550+\mathrm{CuO}$ combinations reduce the viscosity of the molten glass, thereby increasing their pour rates. 


\section{Distribution:}

J. W. Amoroso, 999-W

A. B. Barnes, 999-W

A. L. Billings, 999-W

A. S. Choi, 773-42A

Y. T. Collazo, DOE-EM

C. L. Crawford, 773-42A

D. A. Crowley, 773-43A

A. P. Fellinger, 773-41A

S. D. Fink, 773-A

B. J. Giddings, 786-5A

A. M. Han, DOE-EM

C. C. Herman, 999-W

C. M. Jantzen, 773-A

F. C. Johnson, 999-W

J. C. Marra, 773-42A

S. L. Marra, 773-A

D. H. Miller, 999-W

D. K. Peeler, 999-W

F. M. Pennebaker, 773-42A

S. P. Schneider, DOE-EM

G. L. Smith, DOE-EM

J. D. Vienna, PNNL 